\title{
Cash Crops and Food Security: A Case of Tea Farmers in Burundi
}

\author{
Pierre C. Bitama ${ }^{1}$, Philippe Lebailly ${ }^{1}$, Patrice Ndimanya ${ }^{2}$, \& Philippe Burny ${ }^{1}$ \\ ${ }^{1}$ Economics and Rural Development Unit, University of Liege-Gembloux Agro-Bio Tech, Belgium \\ 2 Rural Economics Unit, University of Burundi, Burundi \\ Correspondence: Pierre C. Bitama, Economics and Rural Development Unit, University of Liege-Gembloux \\ Agro-Bio Tech, Belgium. Tel: 324-6787-4142. E-mail: pierreclaverbitama@yahoo.fr
}

Received: January 16, 2020

doi:10.5539/ass.v16n7p81
Accepted: May 14, 2020 Online Published: June 29, 2020

URL: https://doi.org/10.5539/ass.v16n7p81

\begin{abstract}
Food security is a genuine challenge in developing countries. To combat food insecurity, various means and strategies are being mobilized. The promotion of cash crops in rural areas is one of the main strategies for improving food security. Accessibility to subsistence staples and stable living conditions for rural farmers are made possible by the relatively high and permanent income from cash crops. This paper addresses the issue of food security by discussing the power of tea crop incomes in a rural tea farming area in Burundi. A survey was conducted in 2019 among 120 smallholder tea farmers in two communes located in the Mugamba natural region of Burundi. The results show that the tea plant contributes significantly to food security for both tea farmers and non-tea farmers. By complementing other livelihood resources, tea incomes improve the food security of smallholder tea farmers. In addition, tea incomes ensure the resilience of smallholder tea farmers during lean seasons and against various shocks. Besides, the perennial nature of the tea plant provides a pension for smallholder tea farmers in their old age.
\end{abstract}

Keywords: accessibility, Burundi, cash crops, food security, tea income

\section{Introduction}

Despite spectacular improvements in agricultural yields worldwide over the past half century, food insecurity, hunger and undernourishment persist on the African continent, particularly in the Horn of Africa, resulting from adverse climatic conditions and drought (Godfray et al., 2010; Food and Agriculture Organisation [FAO], International Fund Agriculture Development [IFAD], \& World Food Programme [WFP], 2013; FAO, 2015; Kuma, Dereje, Hirvonen, \& Minten, 2019). Africa is also facing rapid population growth, which is having a negative impact on the capacity of countries on the continent to ensure food availability and accessibility (Dixion, Gulliver, \& Gibbon, 2001; FAO, 2015). Food security is the ability of a country or region to ensure long-term physical and economic access to safe and nutritious food for all its people in order to meet food and dietary preferences for an active and healthy life (World Bank [WB], 1986; FAO, 2008). Food security is therefore ensuring both an adequate food supply in terms of quality, quantity and accessibility. Food security is influenced by both micro and macro-level factors such as technology, institutional support to farmers and merchants, price, monetary and fiscal policy, etc. Food insecurity can be a temporary (e.g. famine resulting from a poor harvest) or a long-term phenomenon (Weber, Staatz, Holtzman, Crawford, \& Bernsten, 1988). Food security is measured on the basis of four elements: availability, accessibility, utilization and stability of food staples. Addressing food and nutritional insecurity is a combination of strategies, means, policies and programmes priorities for economic growth (FAO, 2009; FAO, IFAD, \& WFP, 2012).

To tackle food insecurity in Africa, the promotion of export crops was based on their potential contribution to agricultural productivity and rural farmers' incomes. During the extension of cash crops, they were seen as consumers of water, land, labour, fertilizer and other inputs, resulting in soil degradation, environmental pollution, increased risk of pests and diseases, etc. (Zeller \& Sharma 2000; Govereh \& Jayne, 2003; Anderman, Remans, Wood, DeRosa, \& DeFries, 2014). As some cash crops require a fairly long period of time to be productive, this was seen as a loss to the land being farmed, raising many concerns and questions for rural farmers. In addition, rural farmers feared the risk of price volatility in local markets and reduced production of basic food commodities leading to food insecurity (Govereh \& Jayne, 2003; Wiggins, Henley, \& Keats, 2015).

Cash crops are perennial (coffee, tea, rubber, sugar cane, palm, etc.) and annual (tobacco, maize, rice, vegetables, 
some fruits, etc.) crops. The distinction between cash crops and food crops is that cash crops are generally targeted for the market while food crops are deemed to be subsistence staples for household or animal consumption (Anderman et al., 2014). However, this distinction is not easy to establish, since subsistence crops may be marketed in the case of large-scale production or to meet other needs. To clear up this confusion, a distinction is made between two types of cash crops: on the one hand, those cultivated exclusively for sale on the national and/or international market. Generally, they are not substantial products to food and undergo several stages of processing before getting the final product. This is the case for coffee, cocoa, cotton, tea, etc. On the other hand, crops that are commodities. These are food crops designed for consumption, but the production can be sold on the market mostly in case of large production: e.g. rice, maize, fruits, vegetables, etc. (Cuong, 2009; Achterbosch, Berkum, \& Meijerink, 2014).

Since the introduction of cash crops in Africa, they have not expanded significantly. In 2011-13, they accounted for 5.7\% of all crops, or 21 million ha compared to 347 million ha of food crops. Cocoa, coffee, palm oil, cotton and sugar cane alone accounted for $5.1 \%$. The remaining, including the tea plant, shared $0.6 \%$ (Wiggins et al., 2015).

The tea plant - Camellia sinensis is a plant of the Theaceae family originating from Southeast Asia and which dates back to the $3^{\text {rd }}$ millennium BC (Balentine, Wiseman, \& Bouwens, 1997; Sharangi, 2009; Sarkar et al., 2016; Mitra, 2017). The tea plant was introduced to Africa in the $19^{\text {th }}$ century. In Burundi, the first studies on the tea plant began at Gisozi Agricultural Research Centre (ISABU) in the province of Mwaro. In 1963, 1966 and 1969 the first state plantations known as "industrial blocks" were established in three tea production complexes: Teza, Rwegura and Tora respectively. Towards the end of the 1960s, the tea plant was popularized in village areas thanks to several projects financed by European donors, notably the European Investment Bank, the Caisse centrale de coopération économique (CCEE), the Agence française de développement, etc. (BM, 2008). Later, two other complexes were established in Ijenda and Buhoro in 1984 and 1992 respectively (FAO, 2016). State owned theiculture is therefore practiced in five complexes: Tora, Ijenda, Teza, Rwegura and Buhoro. Later, extensions in both state and village areas have been carried out and the increase in production has followed (Chart 1). In 2018, national production was 50,820 tonnes of green leaves (GL) on an area of 10,005 hectares. Nearly $80 \%$ of the theiculture is located on arable land in village areas with an average of 10 ares per farmer. Since 2010 , more than $72 \%$ of the G L production comes from village areas.

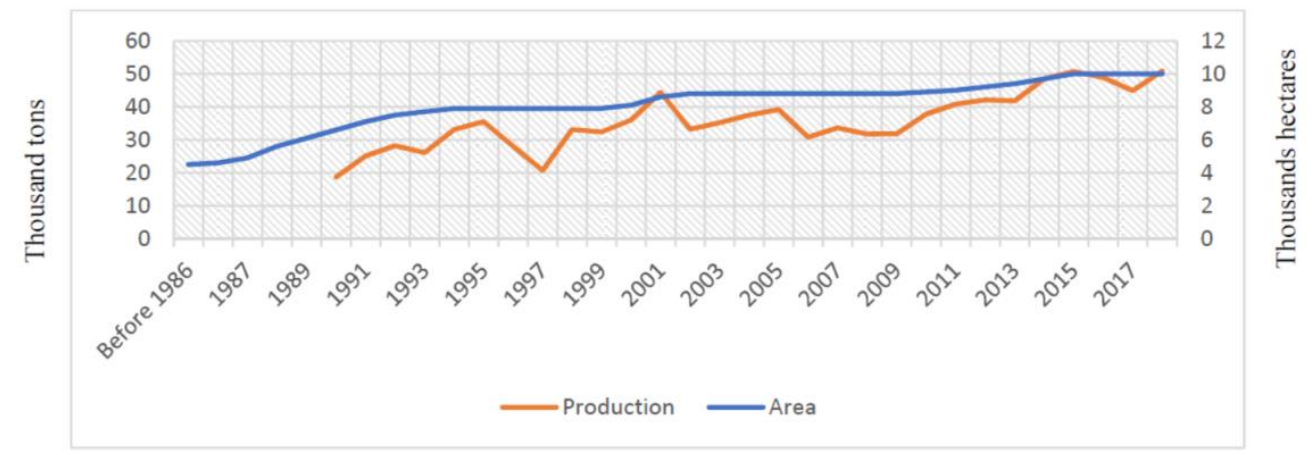

Chart 1. Trend in tea green leaves production (in thousand tons) in Burundi Source: OTB, 2018

The Tea Board of Burundi (OTB) is responsible for the management, control and regulation of the tea industry. The tea plant is a cash crop of vital importance to Burundi's economy. It is the second largest export crop after coffee, accounting for an average of $22.8 \%$ of the value of exports in 2017. It is the $2^{\text {nd }}$ strategic sector for the country in terms of export earnings (Office Burundais des Recettes [OBR], 2017). This article sheds light on the relevance of the tea plant to food security in the households of tea farmers by answering the question: How and to what extent does the tea plant contribute to household food security?

\section{Methodology}

\subsection{Study Area}

The study is located in two communes (Mugongomanga and Bukeye) of the tea growing complexes of Ijenda and Teza respectively. It is in these two communes that the two factories - Ijenda and Teza tea GL processing plants of the two complexes are located. The country has 5 state factories (Tora, Ijenda, Teza, Rwegura and Buhoro) and one private factory (Pojet Théicole de Mwaro-PROTEM). Tea production in Burundi is located in 
the natural region of Mugamba (Figure 1). Due to time and financial constraints, we have chosen the two communes because of their geographical location. They are located near the capital (Bujumbura) of the country. The commune Mugongomanga is located $42.8 \mathrm{~km}$ away from the capital by taking the RN7 and the commune Bukeye is located $54.9 \mathrm{~km}$ away from Bujumbura by taking the RN1. The recent population census of 2008 estimated the population at 27,985 and 66,090 inhabitants in Mugongomanga and Bukeye respectively.

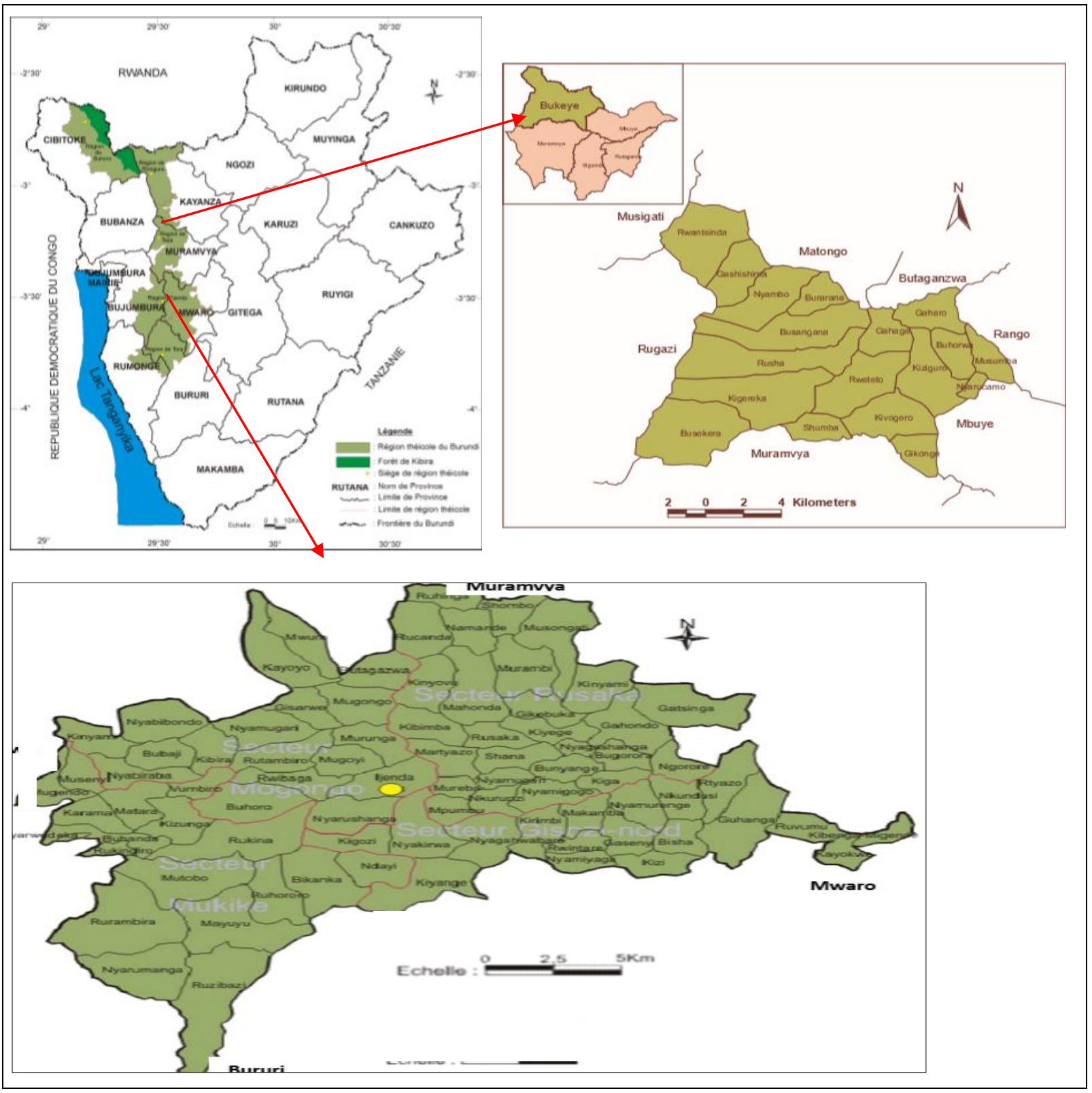

Figure 1. Map of study sites

Source: OTB, 2018

Both sites are located on the hillsides of the Congo-Nile Rift massif with abundant rainfall (average 1400-1500 $\mathrm{mm}$ ) and temperature is between $15^{\circ}-21^{\circ} \mathrm{C}$ (Flémal, 1986). The rural farmers of these two sites live mainly on subsistence agriculture. Food crops in these areas are rainfed and marshland cultivation. In Mugongomanga commune, crops are less diversified than in Bukeye commune because of the absence of marshlands. Thus, the food crops are: potato, maize, beans, sweet potato, cassava, wheat, peas, vegetables (cabbage, carrot, leek, onions, squash, etc.). Livestock consists of large livestock (cattle) and small livestock (goats, sheep, pigs, chickens and rabbits). Tea is grown largely on small areas of less than 10 ares.

\subsection{Materials and Methods}

To answer the question of the relevance of the tea plant to food security, a survey was conducted in 
August-October 2019 among 60 smallholder tea farmers in each of the two communes using triangulation observation, qualitative and quantitative methods. A similar survey was conducted in 2018 in both sites with smallholder tea farmers and OTB's managers on socio-demographic aspects, resources, constraints and resilience strategies as well as the form of governance exercised in the tea sector. For the present study, qualitative data were gathered through semi-structured interviews and focus groups were organized. Secondary data were collected from the two processing plants - Teza and Ijenda - and desk research was used to complete our investigations. The sampling technique used was random sampling. The sample was chosen from an annual tea income (2018) of 598 and 348 smallholder tea farmers in Mugongomanga and Bukeye respectively. This period is considered normal as the pruning of the tea plant for both zones was planned for 2019. The income of tea growers varies throughout the year as shown by the statistical income differences in the sample (Table 1). The difference in income depends on several factors: the size of the plantation, the quality of the soil on which the tea plant is cultivated, the availability of labour, the maintenance of the plantation, etc.

Table 1. Statistical income (in Burundian franc) gaps for tea growers

\begin{tabular}{ccc}
\hline & Mugongomanga & Bukeye \\
\hline Minimum & 24,250 & 15,250 \\
Maximum & 476,625 & $1,408,125$ \\
Average & 175,208 & 200,523 \\
Standard deviation & 122,712 & 196,425 \\
\hline
\end{tabular}

Source: survey, 2019

For the sample from Mugongomanga, the minimum annual income is 24,250 BIF (Burundian franc) and the maximum income is $476,625 \mathrm{BIF}$. The average is $175.208 \mathrm{BIF}$ and the standard deviation is 122712 . On the other hand, the minimum income for the Bukeye's sample is $15,250 \mathrm{BIF}$ and the highest annual income is $1,408,125 \mathrm{BIF}$. The annual average is $200,523 \mathrm{BIF}$ and the standard deviation is 196,425 .

In order to better analyse the importance of tea income to food security, the food crop production was valued. The quantity produced was estimated on the basis of what the tea growers told us. For prices, we used the average annual prices of food crops recorded by the Institute of Statistics and Economic Studies of Burundi (ISTEEBU). The analysis and interpretation of the results were carried out through content analysis (Patton, 2002; Hsieh \& Shannon, 2005; Duriau, Reger, \& Pfarrer, 2007; Srivastava \& Thomson, 2009; Elo et al., 2014; Gheyle \& Jacobs, 2017). The analysis of food security in its various components is complex. Its correct measurement in its different components has been the subject of vast literature (see Carletto, Zezza, \& Banerjee, 2013; Coates, 2013; Bertelli \& Macours, 2014). This paper is mainly limited to one factor - the accessibility.

\section{Results}

\subsection{Tea Incomes in Food Security}

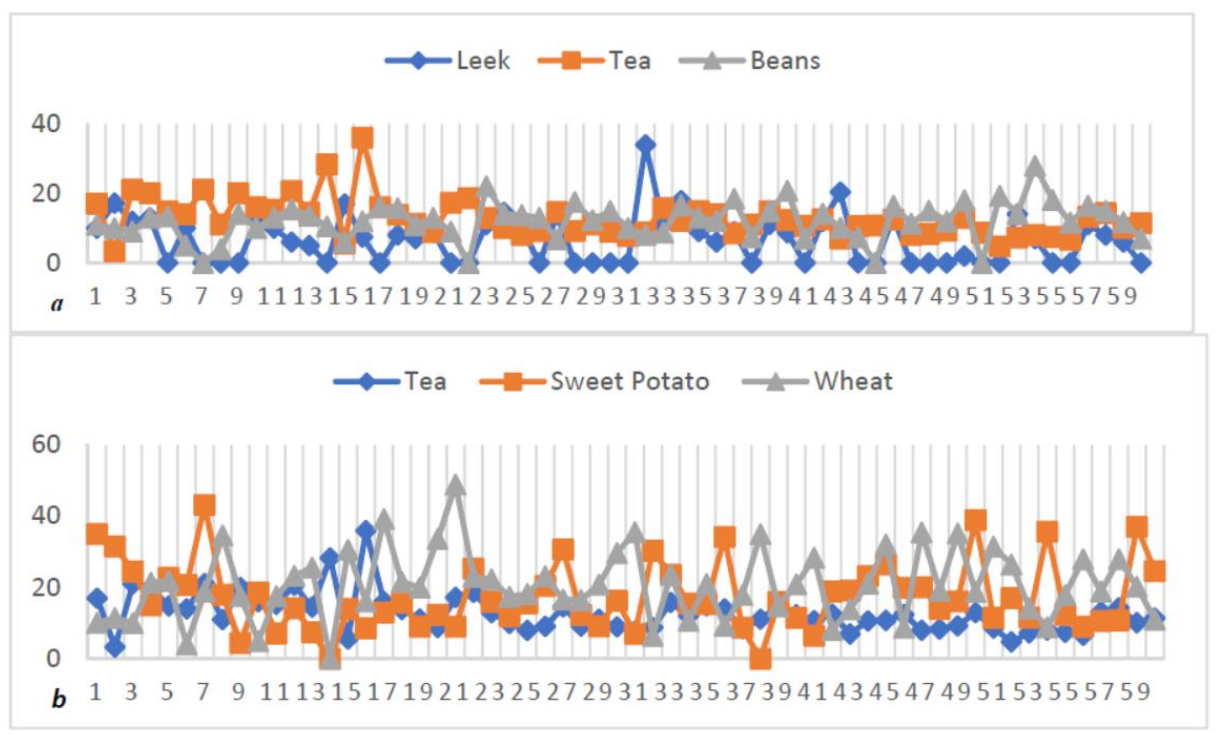

Chart 2. Tea income (in \%) in the valued food crops production in Bukeye commune Source: Survey, 2019 
Our survey revealed that the availability and accessibility of livelihood to tea growers depend on several resources: food staples produced or purchased with the income from the tea plant, sale of livestock, financial resources through leasing of arable land, donations from Non-Governmental Organizations, financial resources from trade, remittances, etc. The incomes from the tea plant are of a special feature. They are regular and are perceived every two months during the entire year. Therefore, they contribute permanently to the accessibility of needed food quantities throughout the year. They are generally low compared to some food-based livelihoods. Indeed, the valuation of the sample's 2018 annual food crop production showed that tea plant income, although continuously earned throughout the year, is lower than the income from the production of some foodstuffs. In Bukeye, more than $70 \%$ of the surveyed farmers have an annual tea plant income that is less important than the income they would have received from the sale of wheat or sweet potato (Chart $2 \mathrm{~b}$ ).

On the other hand, the income from the tea plant is higher than the income that tea growers would have received from other crops such as leeks, beans, potato, corn, etc. (Chart 2a).

In Mugongomanga, more than $80 \%$ of survey farmers have annual tea plant income that are less than the revenues they would have received from the sale of their entire annual potato or maize production (Chart $3 \mathrm{c}$ ) and the income from the tea plant is higher than the income that tea growers would have had from beans, wheat, sweet potato, etc. (Chart $3 \mathrm{~d}$ ).

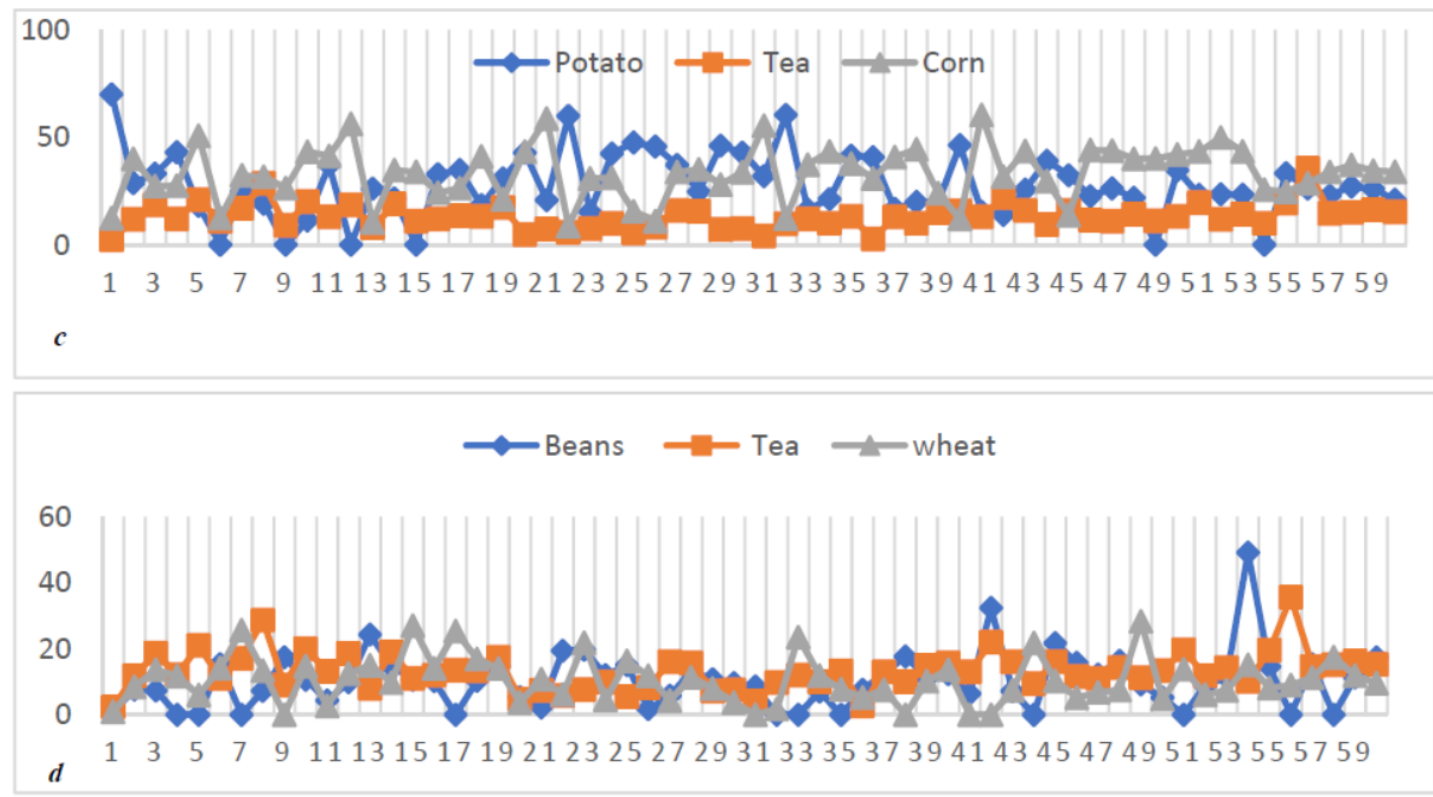

Chart 3. Tea income (in \%) in the valued food crops production at Mugongomanga Source: Survey, 2019

It is obvious that tea plant incomes, even regular, cannot ensure the survival of smallholder tea farmers throughout the year. They are complementary to the livelihood from food crops and other sources of income. If smallholder tea farmers did not grow wheat, maize, potato, sweet potato, beans, etc., the availability and accessibility of food staples would be problematic for them and they would be in extreme poverty. Some smallholder tea farmers with less diversified resources rely on the sale of their labour force. With little diversification of food crops in the Ijenda area, the number of smallholder tea farmers is higher than in the Teza area. In 2015, the OTB identified 12,000 tea growers in Ijenda compared to 10,578 in Teza. Depending on the available income from the tea plant, smallholder tea farmers can have a continuous supply of basic foodstuffs, including cooking salt, palm oil, maize, cassava and/or wheat flour, beans, inputs, etc. Smallholder tea farmers below average incomes told us that the tea plant's income mainly met basic food needs.

In Burundi, the availability and accessibility of food is a constraint for tea growers for the whole year. The months of January-April are a period characterized by a total destocking of food crops and there is an absence of new harvests. During this period, the shock linked to the lack of food is severe. This shock is exacerbated by the reduced availability of food on local markets, as food prices rise dramatically. The stability of food security for tea farmers during these months is under serious threat. In March-April, the situation deteriorates further. Some smallholder tea farmers in Bukeye live on bean leaves and sweet potato or on the latter only. It is the income from the tea plant that allows them to overcome this lean period, which is called "mugasombera". During this 
period tea production is generally abundant compared to other periods (Chart 4).

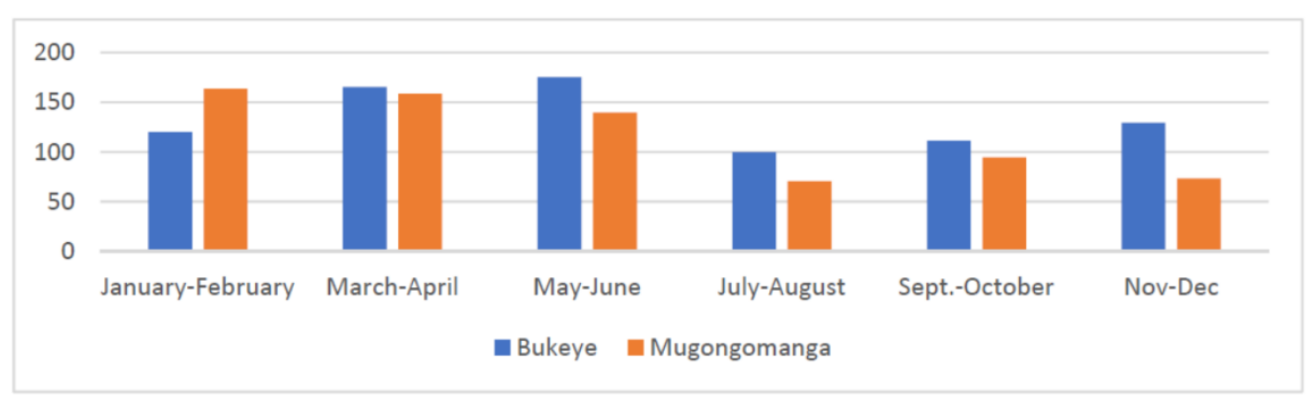

Chart 4. Average production (in $\mathrm{kg}$ ) of smallholder tea farmers in 2018 Source: OTB, 2019

During the lean season, tea growers with poor tea income rely on the most essential foodstuffs such as cooking salt and palm oil to give the bean leaves some flavour. In addition to these most essential foodstuffs, farmers with tea earnings above the average incomes purchase beans, maize or wheat flour on the local markets. Indeed, our field observation has shown that those farmers have a higher living standard than those with low tea plant income.

The climatic hazards to food crops are a major shock to smallholder tea farmers. In the event of climatic hazards, only tea growers with relatively high incomes and other sources of income can endure famine without difficulty during such periods. While tea farmers with low income from the tea plant have difficulties to cope with the period of climatic hazards, non-tea farmers are the most severely affected. "No one could curse the tea plant with lightning," said the smallholder tea farmers.

In Burundian culture, it is customary to donate livestock (cow, goat, sheep, etc.), a portion of land or other property. Young men may inherit arable land from their fathers in order to get married. The tea plant is not subject to this kind of donation: one can inherit everything but not the tea plant before the death of its owner!

\subsection{Livestock}

Livestock contributes to food security both directly (through milk, eggs and meat consumed in households) and indirectly through its sale on the market in quest of income to purchase food, goods and the provision of organic manure to increase production (Otte \& Chilonda, 2002; Achterbosch et al., 2014). Since the introduction of the tea plant in Burundi, smallholder tea farmers have been investing in livestock. At the time of our survey, some of the smallholder tea farmers told us that they had acquired livestock with the sole income from the tea plant (Table 2).

Table 2. Acquisition of livestock (in \%) from tea plant income

\begin{tabular}{ccc}
\hline Type of livestock & Mugongomanga & Bukeye \\
\hline Goats & 40 & 36 \\
Sheep & 48 & 0 \\
Pigs & 33 & 64 \\
Poultry & 77 & 70 \\
Cattle & 0 & 0
\end{tabular}

Source: survey, 2019

In the two sites, livestock is purchased by tea farmers who have a relatively high income. As previously mentioned, the rest of the tea growers have limited means, with tea plant income being used mainly to purchase food stuffs. Furthermore, the weakness in the acquisition of small livestock through tea plant income is explained by the purchasing power that is deteriorating from day to day. The poultry purchase through sole tea incomes is very high. This is explained by their very low acquisition cost. Small livestock farming is very flexible: it does not require a lot of financial means (fodder, housing) and it is multiplying rapidly. It makes it possible to face a food shock in the short run. The sale can be deferred in time and has no repercussions on its multiplication. Raising large livestock (cattle) is part of a mid-term project. Its purchase price at the time of our surveys was in the range of 300,000-500,000 BIF. Its purchase is made from the income of the tea plant as a complement to other sources of income. 


\subsection{Credit System}

In rural areas and in the study sites in particular, financial services among smallholder tea farmers are provided by Micro Finance Institutions (MFIs). Guarantees are required for the granting of loans, as they reduce the exposure of the MFIs to repayment risk (Gaisina, 2010). Etymologically, credit comes from the Latin word "creditum" from the verb "credere" which means to believe or to trust. Granting a credit means having confidence in someone's solvency of a real good, either by the same good or the equivalent within a certain period of time, most often with remuneration for the service provided and the danger involved, the danger of partial or total loss that the very nature of this service entails. As the root of the word suggests, credit requires that one party believes that the other will keep its word and repay the loan obtained (Guinnane, 2010). Although the tea plant income is the only collateral - land and good furniture are not mortgaged, MFIs may judge the collateral insufficient for the amounts requested. Thus, tea farmers whose tea income is below a certain limit have difficulties to access to loans in MFIs. 50\% and 53\% of tea farmers in Mugongomanga and Bukeye respectively have been denied loans because of their insufficient annual incomes. The granting of credit is highly dependent on repayment capacity in addition to the guarantee. The credits obtained can be spent on the purchase of food goods or on other needs.

The creation of associations of tontines by smallholder tea farmers has made possible to meet certain financial and household needs. The amounts can be fairly large (10,000-100,000 BIF). Repayment is usually made from the tea income. Non-compliance with repayment deadlines is charged at a higher interest rate. Thanks to the tea plant income, a loan can be requested from a third party and repayment can be staggered over time. One of the smallholder tea farmers said: "Thanks to the tea plant, the lenders trust us.... Whoever has the tea plant has a treasure. If they see that you are plucking the GL from the tea plant, no one can deny you a debt. ». Debts are contracted from shopkeepers in food crops, soaps, inputs, local and/or industrial beer, etc. The shopkeeper and/or the third party are not afraid of the bankruptcy of their investments due to irrecoverable debts. The forced recovery of the debts from the creditors by the intervention of the notables "the Bashingantahe", is done thanks to the regular income of the tea plant.

\section{Discussion}

The income from the tea plant is complementary to the other sources of incomes (Eriksen, Brown, \& Kelly, 2005; Frelat et al., 2016). In addition, the tea plant's regularity of income gives it an intrinsic importance as a cash crop in Sub-Saharan Africa countries, as well as in Asia. Tea as cash crop contributes to the improvement of people's living standards and food security (Poulton, Al-Hassan, Cadisch, Reddy, \& Smith, 2001; Manivong \& Cramb, 2008; Cuong, 2009; Yi, Cannon, Chen, Ye, \& Swetnam, 2014; Zhang, Kono, \& Kobayashi, 2014; Ulrik, Saurabh, \& Finn, 2016). Thanks to regular income and high amounts compared to other sources of income, cash crops have strong positive effects on food security in many countries. The cultivation of cotton in Peru (Escobal, Agreda, \& Reardon, 2000) and Zimbabwe (Govereh \& Jayine, 2002) provides more financial resources than the agricultural production of commercial food crops. Horticulture (pineapples and mangoes) for export in Ghana provides important income for food security (Afari-Sefa, 2007). Oil palm provides a much higher income than food crops for farmers in Indonesia (Orth, 2007; Feintrenie, Schwarze, \& Levang, 2010; Rist, Feintrenie , \& Levang, 2010), Cameroon (Carrère, 2010; Hoyle \& Levang, 2012; Nkongho, Feintrenie, \& Levang, 2014) and Nigeria (Ibitoye, Akinsorotan, Meludu, \& Ibitoye, 2011; Adebo, Ayodele, \& Olowokere, 2015). Sugarcane provides higher income than food crops in Kenya (Kennedy \& Cogill, 1987; Kennedy, 1989; Kidula-Lihasi, Onyango, \& Ochola, 2016), Zambia and Zimbabwe (Shumba, Roberntz, \& Kuona, 2011). Tobacco is a very attractive cash crop. In Malawi (in 1990), its profit margin was ten times higher than that of maize (Orr, 2000; Drope, Makoka, Lencucha, \& Appau , 2016). In Ethiopia, coffee farmers are highly dependent on coffee income. Coffee income is the main source of livelihood because coffee farmers are less food insecure (Petit, 2007; Kuma et al., 2019). Additionally, banana production in Ethiopia plays a significant role for the wellbeing of the community in terms of food security, income source and serving as source of feed for livestock (Alemu, 2017).

Some studies have shown negative profit margins for cash crops, which keep farmers in extreme poverty. Cocoa producers in West Africa have remained in notorious poverty despite years and years of cocoa farming (Asamoah, Ansah, Anchirinah, Aneani, \& Agyapong, 2013). Latin America (in Nicaragua) producers experienced coffee low incomes (Bacon et al., 2014). This lack of profitability is explained by the non-optimal use of production factors, including agronomic factors (low and/or poor application of fertilizers, small areas, infertile soils, etc.), lack of labour, human and material capital (Kilian, Jones, Pratt, \& Villalobos, 2006; Barham, Callenes, Gitter, Lewis, \& Weber, 2011; Donovan \& Poole, 2014). In Malawi, a negative correlation between food security and higher tobacco income has been reported (Masanjala, 2006). This is a result of inefficient management at the household level. In Africa, men are the heads of the household and money may be withdrawn from women to purchase 
household food staples, with men spending the earnings on luxury goods or alcohol (Poulton et al., 2001).

In addition to their regular income, cash crops enable smallholder tea farmers to overcome the lean season (Anderman et al., 2014; Alemu, 2017; Kuma et al., 2019). The resilience of the tea plant to climatic hazards and its permanent income throughout the year in Burundi give the tea plant an intrinsic value compared to other income sources. Aside from climatic hazards, the tea's income provides smallholder tea farmers with food stability and prevents them from putting non-perishable food commodities on the market as soon as they are harvested to meet urgent needs; a period during which prices are generally low. Moreover, decapitalization can also be avoided through tea plant income (Martha \& Johan, 2012; Kuma et al., 2019). Food crops are at risk from conservation systems. The logistics of perishable products is a major problem, as tea growers do not have adequate storage systems (neither cold rooms nor refrigerators). Some products at harvest must be consumed the same day, especially vegetables and fruits (tomatoes, carrots, mushrooms, etc.). At harvest, food crops are available on the market in large quantities because they are harvested at the same time. The lack of a grain storage system is also a challenge for tea farmers. Due to a lack of knowledge of storage techniques, the stored cereals are attacked by weevils or rot.

The tea plant is a perennial plant that maintains a better yield for decades if well maintained. Tea plants need at least three years to reach maturity. After this period, a regular plucking (once every 11 days and once every 8 days during periods of high production) of GL can begin. The economic life of the plant is about 40 years, but sometimes the trees are kept in production for a period of 60-70 years or even 100 years (Conférence des Nations Unies sur le Commerce et le Développement [CNUCED], 2016). This character means that the tea plant is exploited from generation to generation. The perennial nature of the tea plant and the regular income from this cash crop assist tea growers in their old age until death. Generally, the income is divided in two parts, one part is handed over to the person who maintains the plantation and does the plucking of the tea's GL, the other part is given to the owner. Rural farmers without tea plants at their old age are miserable and their death is hastened by lack of means of subsistence because the tea plant at that age is considered as a form of pension. In addition, working in the tea industry at the upstream level of the chain provides a source of livelihood for non-tea farmers for pruning, mulching and plucking (Poulton et al., 2001; Wiggins et al., 2015; Ulrik et al., 2016). The establishment and maintenance of means of communication facilitate access to food and other means of well-being for tea growers available in the various local markets (Weber et al., 1988).

Although tea plant incomes are low for the majority of tea farmers, their regularity provides opportunities for them to invest in livestock to diversify income sources in order to build up resilience and accumulate assets and income (Achterbosch et al., 2014; Ulrik et al., 2016). Moreover, saving in kind rather than hoarding at home is more secure!

The availability and accessibility of credit play an important role in the lives of rural farmers. The allocation of credits obtained thanks to the income of the tea plant (Govereh \& Jayne, 2003; Wiggins et al., 2015), strengthens resilience to inaccessibility to food assets and allows income accumulation through the acquisition of fixed assets such as arable land or other assets whose acquisition cost requires a large sum of money (e.g. the purchase of cattle). These credits may also be allocated for the start-up of a commercial activity (Anderson, 2003; Govereh \& Jayne, 2003). Through credits contracted in the associations of tontines, tea growers meet urgent needs related to diseases or a temporary shortage of food goods due to a poor harvest (Fafchamps, 1999; Anderson, 2003; Hussain \& Thapa, 2012). The supervision of the tontine associations seems to us indispensable to broaden their mode of operation and their scope of action. Through its regular income and its less risky aspect, the tea plant creates a climate of trust between the smallholder tea farmers and the village community. The tea plant is a collateral, a mortgage, a commodity that creates confidence in the village community and the credit obtained strengthens the food security of tea growers (Poulton, Dorward, \& Kydd, 1998; Govereh \& Jayne, 2003; Wiggins et al., 2015).

However, in Burundi the tea plant is not a plant with virtues only. Indeed, any agricultural sector is subject to risks. One of the risks related to cash crops is price volatility on international markets, with adverse consequences along the chain (Afari-Sefa, 2007; Achterbosch et al., 2014; Ulrik et al., 2016). The volatility of world tea prices has made the guaranteed (and effective) price of GL to be maintained at $250 \mathrm{BIF} / \mathrm{kg}$ for a whole decade. However, with the depreciation of the Burundian currency, foodstuffs are bought at much higher price (three or four times or even five times) than the price per $\mathrm{kg}$ of GL. Another consequence of the rigid price $/ \mathrm{kg}$ of the GL is the lack of financial resources for paid labour in the tea plant sector in case of absence or shortage of family labour. In addition, the hiring of paid labour results in lower profit margins (Owuor \& Kwach, 2012; Rymbai, Singh, Feroze, \& Debbarma, 2012; Upreti, 2015). The absence of labour in the plantation disrupts the rotational harvesting cycle, generating poor yields in the short and medium term. The country is experiencing a 
situation of land scarcity due to demographic pressure and the younger generations tend to favour the exploitation of food crops rather than tea plants, even though they are fragile vis-à-vis the climatic hazards. Monocropping in the tea plantation is an opportunity cost of maximizing the use of arable land in a context of scarcity (Buragohain, 2015).

\section{Conclusion}

Cash crops remain an important part of the economic life of countries and rural farmers, particularly in terms of food security. As a strategic cash crop at the national level in terms of foreign exchange earnings, tea is a crop of resilience to shocks and accumulation of survival (financial and non-financial) resources for rural farmers thanks to its regular income and its resistance to climatic hazards. Tea cultivation is a long-term investment due to its perennial nature. It is exploited from generation to generation and is a pension for small-scale tea farmers in their old age. The tea plant provides employment opportunities for non-tea farmers, allowing them access to livelihood sources. In complementarity with other food-based livelihoods and other sources of income, tea plant income plays the dual role of stability and accessibility to the livelihood, an important safeguard to food security. In areas with favourable soil and climatic conditions for tea, a tea plantation, regardless of its size, would be an ideal as a strategy for diversifying the sources of livelihood (Luckert, Wilson, Adamowicz, \& Cunningham, 2000; Anderson, 2003; Luke, Job, \& Bernard, 2011). State authorities should conceive and implement programmes and mechanisms that simultaneously maximize crop yields (food and cash crops) and limit climatic risks. They need to experiment with solutions to the constraints of the tea industry (e.g. intercropping tea plant with other crops) while improving the quality of the tea sold. Building innovation and entrepreneurial capacity among smallholder tea farmers should be a springboard for combating food insecurity.

\section{Acknowledgements}

The authors are very grateful to the factory managers and tea growers who kindly took the time to answer their questions.

\section{References}

Achterbosch, T., Berkum, S., \& Meijerink, G. (2014). Cash crops and food security:Contributions to income, livelihood risk and agricultural innovation. LEI report, Wageningen-Netherlands.

Adebo, G. M., Ayodele, O. J., \& Olowokere, K. (2015). Palm oil production as a poverty alleviation strategy among small-scale farmers in Ekiti State, Nigeria. World Journal of Agricultural Research, 3(2), 43-48. https://doi.org/10.12691/wjar-3-2-1

Afari-Sefa, V. (2007). The distributional effects of horticultural export value chains among smallholders in southern Ghana. African Association of Agricultural Economists (AAAE) Conference Proceedings, 295-299. https://doi.org/10.22004/ag.econ.52124

Alemu, M. M. (2017). Banana as a cash crop and its food security and socioeconomic contribution: The case of southern Ethiopia, Arba Minch. Journal of Environmental Protection, 8, 319-329. https://doi.org/10.4236/jep.2017.83024

Anderman, T. L., Remans, R., Wood, S. A., DeRosa, K., \& DeFries, R. S. (2014). Synergies and tradeoffs between cash crop production and food security: A case study in rural Ghana. Food Sec., 6, 541-554. https://doi.org/10.1007/s12571-014-0360-6

Anderson, J. R. (2003). Risk in rural development: Challenges for managers and policy makers. Agricultural Systems, 75, 161-197. https://doi.org/10.1016/S0308-521X(02)00064-1

Asamoah, M., Ansah, F. O., Anchirinah, V., Aneani, F., \& Agyapong, D. (2013). Insight into the standard of living of Ghanaian cocoa farmers. Greener Journal of Agricultural Sciences, 3(5), 363-370.

Bacon, C. M., Sundstrom, W., Gómez, M. E. F., Méndez, V.E., Santos, R., Goldoftas, B., \& Dougherty, I. (2014). Explaining the 'hungry farmer paradox': Smallholders and fair-trade cooperatives navigate seasonality and change in Nicaragua's corn and coffee markets. Global Environmental Change, 25, 133-149. https://doi.org/10.1016/j.gloenvcha.2014.02.005

Balentine, D. A., Wiseman, S. A., \& Bouwens, L. C. M. (1997). The chemistry of tea flavonoids. Critical Reviews in Food Science \& Nutrition, 37(8), 693-704. https://doi.org/10.1080/10408399709527797

Barham, B. L., Callenes, M., Gitter, S., Lewis, J., \& Weber, J. (2011). Fair trade/organic coffee, rural livelhoods, and 'agrarian question': Southern Mexican families coffee in transition. World Development, 39(1), 134-145. https://doi.org/10.1016/j.worlddev.2010.08.005 
Bertelli, O., \& Macours, K. (2014). Food security and agriculture in developing countries: Measurement and hypotheses for impact evaluations. Foodsecure working paper, 21, Brussels: LEI Wageningen UR.

BM. (2008). Rompre le cercle vicieux. Une stratégie pour promouvoir la croissance dans un milieu rural sensible aux conflits au Burundi. B.M, Washington, DC. https://doi.org/10.1596/978-0-8213-7563-1

Buragohain, R. (2015). Identification of intercrops in small tea plantations at Golaghat district of Assam, India. India J. Agr. Res., 49(3), 290-293. https://doi.org/10.5958/0976-058X.2015.00048.7

Carletto, G., Zezza, A., \& Banerjee, R. (2013). Towards better measurement of household food security: Harmonizing indicators and the role of household surveys. Global Food Security, 2(1), 30-40. https://doi.org/10.1016/j.gfs.2012.11.006

Carrère, R. (2010). Le palmier à huile en Afrique: le passé, le présent et le futur. Mouvement Mondial pour les Forêts Tropicales. Collecion du WRM sur les plantations, $\mathrm{n}^{\circ} 15$.

CNUCED. (2016). Le thé: un profil de produits de base par INFOCOMM. New York et Génève: Fonds de la CNUCED pour l'information sur les marchés des produits de base agricoles.

Coates, J. (2013). Build it back better: Deconstructing food security for improved measurement and action. Global Food Security, 2, 188-194. https://dx.doi.org/10.1016/j.gfs.2013.05.002

Cuong, N. V. (2009). Measuring the impact of cash crops on household expenditure and poverty in rural Vietnam. Asia-Pacific Development Journal, 16(2), 87-112.

Dixion, J., Gulliver, A., \& Gibbon, D. (2001). Farming systems and poverty: Improving farmers' livelihoods in a changing world. FAO and the World Bank: Rome, Italy.

Donovan, J., \& Poole, N. (2014). Changing assets endowments and smallholder participation in high value markets: Evidence from certified coffee in Nicaragua. Food Policy, 44, 1-13. https://doi.org/10.1016/j.foodpol.2013.09.010

Drope, J., Makoka, D., Lencucha, R., \& Appau, A. (2016). Farm-level economics of tobacco production in Malawi. The Economics of Tobacco Farming in Malawi.

Duriau, J. V., Reger, R. K., \& Pfarrer, M. D. (2007). A content analysis of the content analysis literature in organization studies: Research themes, data sources, and methodological refinements. Organizational Research Methods, 10(5). https://doi.org/101177/1094428106289252

Elo, S., Kääriäinen, M., Kanste, O., Pölkki, T., Utriainen, K., \& Kyngäs, H. (2014). Qualitative content analysis: A focus on trustworthiness. SAGE Open, 1-10. https://doi.org/10.1177/2158244014522633

Eriksen, S., Brown, K., \& Kelly, P. M. (2005). The dynamics of vulnerability: Locating coping strategies in Kenya and Tanzania. The Geographical Journal, 174(4), 287-305.

Escobal, J., Agreda, V., \& Reardon, T. (2000). Endogenous institutional innovation and agroindustrialization on $\begin{array}{lllll}\text { the Peruvian } \quad \text { coast. } & \text { Agricultural 267-277. }\end{array}$ https://doi.org/10.1111/j.1574-0862.2000.tb00278.x

Fafchamps, M. (1999). Risk sharing and quasi-credit. Journal of International Trade \& Economic Development, 8(3), 257-278. https://doi.org/10.1080/09638199900000016

FAO. (2008). An introduction to the basic concepts of food security, food security information for action practical guide. EC-FAO Food Security Programme.

FAO. (2009). The state of food insecurity in the world 2009: Economic crises-impacts and lessons learned. Rome: FAO.

FAO. (2015). Regional overview of food insecurity: African food insecurity prospects brighter than ever. Accra: FAO.

FAO. (2016). Analyse des incitations par les prix pour le thé au Burundi, par Emera, W., Ntwengeyabandi, A. et Ghins, $L$. Série de notes techniques, SAPAA, Rome.

FAO, IFAD, \& WFP. (2012). The state of food insecurity in the world. Economic growth is necessary but not sufficient to accelerate reduction of hunger and malnutrition. Rome: FAO.

FAO, IFAD, \& WFP. (2013). The state of food insecurity in the world 2013. The multiple dimensions of food security. Rome: FAO.

Feintrenie, L., Schwarze, S., \& Levang, P. (2010). Are local people conservationists? Analysis of transition 
dynamics from agroforests to monoculture plantations in Indonesia. Ecology and Society, 15(4).

Flémal, J. (1986). La culture du théier au Burundi. Institut des Sciences Agronomiques du Burundi. Bujumbura.

Frelat, R., Lopez-Ridaura, S., Giller, K. E., Herrero, M., Douxchamps, S., Djurfeldt, A. A., ...Wijk, M. T. (2016). Drivers of household food availability in sub-Saharan Africa based on big data from small farms. PNAS, 113(2), 458-463. https://doi.org/10.1073/pnas.1518384112

Gaisina, S. (2010). Access to bank credit by agricultural producers in Kazakhstan: A micro-econometric analysis. The International Journal of Economic Policy Studies, 5(3), 33-48. https://doi.org/10.1007/BF03405726

Gheyle, N., \& Jacobs, T. (2017). Content analysis: A short overview. Internal research note. Centre for EU Studies, Ghent, Belgium.

Godfray, H. C. J., Beddington, J. R., Crute, I. R., Haddad, L., Lawrence, D., Muir, J. F., ... Toulmin, C. (2010). Food security: The challenge of feeding 9 billion people. Science, 327(5967), 812-818. https://doi.org/10.1126/science. 1185383

Govereh, J. \& Jayne, T.S. (2003). Cash cropping and food crop productivity: Synergies or trade-offs? Agricultural Economics, 28, 39-50. https://doi.org/10.1111/j.1574.0862.2003.tb00133.x

Guinnane, T. W. (2010). Les économistes, le crédit et la confiance. Génèse, 2(79), 6-25.

Hoyle, D., \& Levang, P. (2012). Oil palm development in Cameroon. WWF report in partnership with IRD and CIFOR.

Hsieh, H. F., \& Shannon, S. E. (2005). Three approaches to qualitative content analysis. Qualitative Health Research, 1277-1288. https://doi.org/10.1177/1049732305276687

Hussain, A., \& Thapa, G. B. (2012). Smallholders' access to agricultural credit in Pakistan. Food Sec., 4, 73-85. https://doi.org/10.1007/s12571-012-0167-2

Ibitoye, O. O., Akinsorotan, A. O., Meludu, N. T., \& Ibitoye, B. O. (2011). Factors affecting oil palm production in Ondo State of Nigeria. Journal of Agriculture and Social Research (JASR), 11(1), 97-105.

Kennedy, E., \& Cogill, B. (1987). Income and nutritional effects of the commercialization of agriculture southwestern Kenya. International Food Policy Reseach Institute.

Kennedy, E. (1989). The effects of sugarcane production on food security, health and nutrition in Kenya: A longitidinal analysis. Research report 78, International Food Policy Research Institute (IFPRI).

Kidula-Lihasi, L., Onyango, C., \& Ochola, W. (2016). Analysis of smallholder sugarcane farmers' livelihood assets in relation to food security in Mumias sub-county Kenya. Journal of Economics and Sustainable Development, 7(20), 40-47.

Kilian, B., Jones, C., Pratt, L., \& Villalobos, A. (2006). Is a sustainable agriculture a viable strategy to improve farm income in central America? A case study on coffee. Journal of Business Research, 59, $322-330$. https://doi.org/10.1016/j.jbusres.2005.09.015

Kuma, T., Dereje, M., Hirvonen, K., \& Minten, B. (2019). Cash crops and food security: Evidence from Ethiopian smallholder coffee producers. The Journal of Development Studies, 55(6), 1267-1284. https://doi.org/10.1080/00220388.2018.1425396

Luckert, M. K., Wilson, J., Adamowicz, V., \& Cunningham, A. B. (2000). Household resource allocations in response to risks and returns in a communal area of western Zimbabwe. Ecological Economics, 33(3), 383-394.

Luke, K. K., Job, L., \& Bernard, K. N. (2011). The role of non-farm investments in agricultural risk management in Kenya. Current Research Journal of Economic Theory, 3(2), 62-68.

Manivong, V., \& Cramb, R.A. (2008). Economics of smallholder rubber expansion in northern Laos. Agroforest Syst, 74, 113-125. https://doi.org/10.1007/s10457-008-9136-3

Martha, N., \& Johan, S. (2012). Biofuels and food security: Micro-evidence from Ethiopia. Discussion paper 319 , Leuven, Belgium.

Masanjala, W. H. (2006). Cash crop liberalization and poverty alleviation in Africa: Evidence from Malawi. Agricultural Economics, 35, 231-240.

Mitra, S. (2017). Health benefits of tea. In Exploring the nutrition and health benefits and functional foods. Unated States of America: IGI Global. 
Nkongho, R. N., Feintrenie, L., \& Levang, P. (2014). Oil crops and supply chain in Africa: Strengths and weaknesses of the smallholder oil palm sector in Cameroon. Oilseeds and Fats,Crops and Lipids (OCL), 21(2). http://dx.doi.org/10.1051/ocl/2013043

OBR. (2017). Statistiques du commerce extérieur des marchandises du Burundi. Bulletin trimestriel du commissariat des douanes accises. Bujumbura. Https://www.obr.bi/images/DAO/Bulletin_Douane_pour_le_site.pdf [Accessed 23 December 2019]

Orr, A. (2000). 'Green gold'?: Burley tobacco, smallholder agriculture, and poverty alleviation in Malawi. World Development, 28(2), 347-363. https://doi.org/10.1016/S0305-750X(99)00127-8

Orth, M. (2007). Subsistence foods to export goods: The impact of an oil palm plantation on local food sovereignty. North Barito and central Kalimantan, Indonesia: Biofuelwatch.

Otte, M. J. \& Chilonda, P. (2002). Cattle and small ruminant production systems in sub-Saharan Africa: A systematic review. Rome: FAO.

Owuor, P. O., \& Kwach, B. O. (2012). Quality and yield of black tea Camellia sinensis L.O. Kuntze in responses to harvesting in Kenya: A review. Asian Journal of Biological and Life Sciences, 1(1), 1-7.

Patton, M. Q. (2002). Qualitative research and evaluation method (3rd ed.). Thousand Oaks, CA: Sage Publication.

Petit, N. (2007). Ethiopia's coffee sector: A bitter or better future? Journal of Agrarian Change, 7(2), 225-263. https://dx.doi.org/10.1111/j.1471-0366.2007.00145.x

Poulton, C., Al-Hassan, R., Cadisch, G., Reddy, C., \& Smith, L. (2001). The cash crop versus food crop debate. Crop Post Harvest Programme (CPHP), (3).

Poulton, C., Dorward, A., \& Kydd, J. (1998). The revival of smallholder cash crops in Africa: Public and private roles in the provision of finance. Journal of International Development, 10(1), 85-103.

Rist, L., Feintrenie, L., \& Levang, P. (2010). The livelihood impacts of oil palm: smallholders in Indonesia. Biodiversity and Conservation, 19, 1009-1024. https://dx.doi.org/10.1007/s10531-010-9815-z

Rymbai, D., Singh, R., Feroze, S. M., \& Debbarma, B. (2012). Factors associated with labour supply for tea plantation and productivity: A case study of tea growers in Meghalaya. Indian Journal of Hill Farming, 25(2), 6-9.

Sarkar, S., Chowdhury, A., Das, S., Chakraborty, B., Mandal, P., \& Chowdhury, M. (2016). Major tea processing practices in India. International Journal of Bioassays, 5(11), 5071-5083. https://dx.doi.org/10.21746/ijbio.2016.11.0015

Sharangi, A.B. (2009). Medicinal and therapeutic potentialities of tea (Camellia sinensis L)-A reveiw. Food Research International, 42, 529-535. https://doi.org/10.1016/j.foodres.2009.01.007

Shumba, E., Roberntz, P., \& Kuona, M. (2011). Assessment of sugarcane outgrower schemes for bio-fuel production in Zambia and Zimbabwe. WWF-World Wide Fund For Nature, Harare (Zimbabwe).

Srivastava, A., \& Thomson, S. B. (2009). Framework analysis: A qualitative methodology for applied policy research. Journal of Administration \& Governance (JOAAG), 4(2), 72-79.

Upreti, P. (2015). Labour scarcity and its implication for farm mechanization in India. New Delhi: Indian Agricultural Research Institute.

Ulrik, B., Saurabh, S., \& Finn, T. (2016). Coffee price volatility and intra-household labour supply: Evidence from Vietnam. Working paper 16, UNU-WIDER, Helsinki.

WB. (1986). Poverty and hunger: Issues and options for food security in developing countries. Washington, DC.

Weber, M. T., Staatz, J. M., Holtzman, J. S., Crawford, E. W., \& Bernsten, R. H. (1988). Informing food security decisions in Africa: Empirical analysis and policy dialogue. American Journal of Agricultural Economics, 70(5), 1044-1052. https://doi.org/10.2307/1241733

Wiggins, S., Henley, G., \& Keats, S. (2015). Competitive or complementary? Industrial crops and food security in sub-Saharan Africa. ODI report. Overseas Development Institute, London.

Yi, Z-F., Cannon, C.H., Chen, J., Ye, C-X., \& Swetnam, R.D. (2014). Developing indicators of economic value and biodiversity loss for rubber plantations in Xishuangbanna, southwest China: A case study from Menglun township. Ecological Indicators, 38, 788-797. https://doi.org/10.1016/j.ecolind.2013.03.016 
Zeller, M. \& Sharma, M. (2000). Many borrow, more save, and all insure: Implications for food and micro-finance policy. Food Policy, 25(2), 143-167. https://doi.org/10.1016/S0306-9192(99)00065-2

Zhang, L., Kono, Y., \& Kobayashi, S. (2014). The process of expansion in commercial banana cropping in tropical China: A case study at a Dai village, Mengla county. Agricultural Systems, 124, 32-38. https://doi.org/10.1016/j.agsy.2013.10.006

\section{Copyrights}

Copyright for this article is retained by the author(s), with first publication rights granted to the journal.

This is an open-access article distributed under the terms and conditions of the Creative Commons Attribution license (http://creativecommons.org/licenses/by/4.0/). 